\title{
藏东地区晚石炭-晚二叠世古地磁新结果: 对羌北-昌都地块构造演化的制约
}

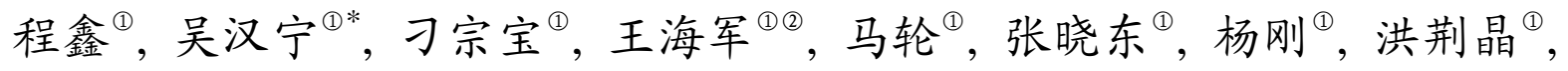
计文化 ${ }^{3}$, 李荣社 ${ }^{3}$, 陈守建 ${ }^{3}$, 赵振明 ${ }^{3}$

(1) 西北大学地质学系, 大陆动力学国家重点实验室, 西安 710069;

(2) 中煤科工集团西安研究院, 西安 710054;

(3) 西安地质矿产研究所, 西安 710054

* 联系人, E-mail: wuhn2506@nwu.edu.cn

收稿日期: 2012-03-16; 接受日期: 2012-09-20; 网络版发表日期: 2013-07-19

国家自然科学基金(批准号: 41074045, 41174055)、中国地质调查局国土资源大调查综合研究项目(编号: 1212010610102)和陕西省普通高 等学校重点学科专项资金(编号: 081802)资助

摘要本文报道藏东地区晚石炭-晚二叠世古地磁研究结果, 获得了 3 个可靠的古地磁极位 置. 对采自 24 个采点(219 块灰岩、玄武岩及泥质粉砂岩)样品的系统古地磁学研究表明: 晚石炭 世灰岩样品中赤铁矿和磁铁矿共存, 其退磁曲线具有典型的双分量特征, 高温特征剩磁(ChRM) 均为正极性(负倾角). 中-晚二叠世灰岩、凝灰岩及玄武岩样品的主要载磁矿物为磁铁矿(部分玄 武岩样品为赤铁矿), 退磁曲线表现为双分量或单分量特征, 其高温特征剩磁均为负极性(正倾 角), 可通过标准的褶皱检验, 且在地层坐标系下中-晚二叠世与晚石炭世特征剩磁方向的单一极 性分别与 Kiaman 反极性期及之前的正极性特征相吻合，应该均为岩石形成时期的原生剩磁信 息. 与美北地区的古地磁结果对比可得: (1) 昌都与羌北地块在晚石炭至早二叠世期间相互独立, 其间的北澜沧江洋盆可能于中二叠世前闭合, 晚二叠一早三叠世进入陆-陆碰撞阶段. (2) 㒸北-昌 都地块晚石炭至晚二叠世期间位于南纬中低纬度地区，早三叠世以后开始大规模北向移动，与 现今位置相比运动总量达 $5000 \mathrm{~km}$ 以上.

关键词 古地磁 特提斯 㒸北地块 晚古生代 北澜沧江带
青藏高原内部多块体间的演化和碰撞拼贴过程 等运动学问题是认识高原内部结构、特提斯洋演化历 史等大地构造问题的关键 ${ }^{[1]}$. 系统的古地磁研究成果 以其对块体的南北向运动和旋转以及块体间相对位 置变化的限定, 为高原内部诸块体的构造古地理格 局和碰撞拼合历史提供了重要线索 ${ }^{[2 \sim 7]}$. 我们曾报道
了㒸北(保护站-热觉茶卡)地区晚石炭-早三叠世古地 磁研究的结果 ${ }^{[8]}$, 厘定了芫北地块在晚石炭-早三叠 世的位置及其变化. 本文报道藏东(诺日巴纳保-周琼 玛鲁)地区晚石炭-晚二叠世古地磁研究的新结果, 并 与芫北地区的古地磁结果对比分析, 为研究羌北-昌 都地块的构造演化和冈瓦纳大陆晚古生代的北界问

中文引用格式: 程金金, 吴汉宁, 刀宗宝, 等. 藏东地区晚石炭-晚二叠世古地磁新结果: 对芫北-昌都地块构造演化的制约. 中国科学: 地球科学, 2013, 43: 13121323

英文引用格式: Cheng X, Wu H N, Diao Z B, et al. Paleomagnetic data from the Late Carboniferous-Late Permian rocks in eastern Tibet and their implications for tectonic evolution of the northern Qiangtang-Qamdo block. Science China: Earth Sciences, 2013, 56: 1209-1220, doi: 10.1007/s11430-012-4558-1 
题 ${ }^{[9,10]}$ 提供依据.

\section{1 区域地层概况与样品采集}

采样地区位于唐古拉山北侧的开心岭隆起带, 该隆起主体发育晚古生代沉积, 呈 NW-SE 向延伸, 其上局部被上三叠统结扎群地层不整合覆盖, 缺失
中、下三叠统沉积(图 1). 区内石炭-二叠系地层由老 到新为：晚石炭世-中二叠世开心岭群 $\left(\left(\mathrm{C}_{1}-\mathrm{P}_{2}\right) k\right)$ 扎日 根组 $\left(\left(\mathrm{C}_{1}-\mathrm{P}_{1}\right) \hat{z}\right)$ 、诺日巴尔日堡组 $\left(\mathrm{P}_{2} n r\right)$ 、九十道班组 $\left(\mathrm{P}_{2} j\right)$; 晚二叠世乌丽群那益雄组 $\left(\mathrm{P}_{3} n\right)^{[11 \sim 13] 1), 2)}$.

扎日根组创名于格尔木市唐古拉山乡扎日根, 层型剖面位于诺日巴纳保。扎日根组区域上分布局 限，与诺日巴尔日堡组、九十道班组、那益雄组以及
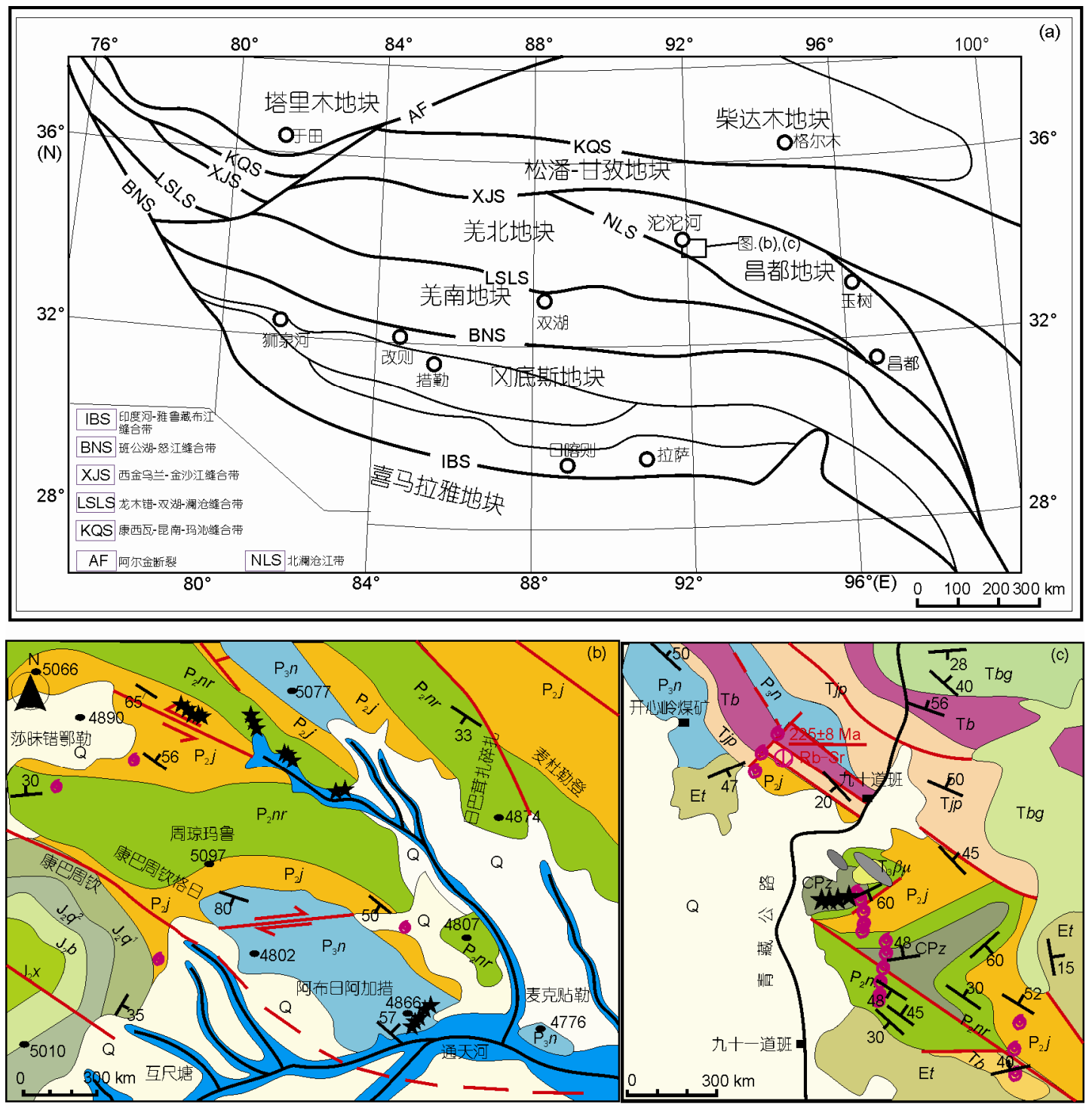

采样点位置 0 化石位置

图 1 研究区大地构造简图(a)及采样区地质简图((b), (c)) 据脚注 1)和 2)修改

1) 青海 1:25 万沱沱河幅(I46C002002)区域地质调查报告. 青海: 青海地质调查院, 2005

2) 青海 1:25 万温泉兵站幅(I46C003002)区域地质调查报告. 四川: 成都理工大学地质调查院, 2005 
三叠纪波里拉组之间皆为断层接触, 未见顶底. 其 岩性为碳酸盐岩, 岩性横向上无变化, 化石丰富, 时代依据准确, 为晚石炭世-早二叠世跨时代的岩石 地层 ${ }^{[11]}$, 本次样品采集于扎日根组中下部, 当属于 上石炭统.

诺日巴尔日堡组、九十道班组分别为碎屑岩组 和碳酸盐岩组, 在采样区组成周琼玛鲁复式背斜. 诺日巴尔日堡组出露面积较宽, 组成背斜核部, 未 见底, 与上覆九十道班组整合接触, 依据其上下两 组层位时代界定, 归属于中二叠统中下部的祥播阶. 该组岩性变化较大, 为碎屑岩夹多套火山岩地层 ${ }^{[12]}$. 九十道班组出露面积也较大, 组成该背斜翼部, 与 上覆那益雄组为平行不整合接触. 主要岩性由深灰 色中层状生物介壳微晶灰岩、鋋灰岩、珊瑚礁灰岩, 含丰富生物化石，依据化石在地层中分布状况，该 组为中二叠世中晚期沉积, 属中二叠统茅口阶和冷 坞阶 ${ }^{[13], 2)}$.

那益雄组仅在周琼玛鲁一带向斜核部出露, 该 组底部见一套紫色含砾砂岩、砾岩, 与下覆九十道班 组较纯的灰色碳酸盐岩沉积相序不连续, 有明显的沉 积间断, 为平行不整合接触, 未见顶. 岩性主要由灰 色、灰绿色、紫色蚀变玄武岩、安山玄武岩、安山粗 面岩和岩屑石英砂岩、粉砂岩、泥页岩组成, 顶部为 紫色薄层硅质岩, 底部为泥质、石英质、钙质砾岩. $1: 25$ 万地质调查报告依据最新的古生物资料, 认为 那益雄组为晚二叠世沉积, 归属上二叠统吴家坪阶 和长兴阶 ${ }^{[13], 2)}$.

本次研究根据研究区地层出露及交通状况, 于 格尔木市唐古拉山乡诺日巴纳保和周琼玛鲁一带共 布置 24 个采点, 采集独立定向样品 219 块(图 1). 其 中, 于诺日巴纳保地区扎日根组的下部层位采样 33 块(4 个采点), 岩性为生物碎屑灰岩. 其他样品均采 集于周琼玛鲁地区, 诺日巴尔日堡组采样 109 块(10个 采点), 岩性主要为泥岩、灰质、粉砂质泥岩和粉砂岩; 九十道班组采样 41 块( 5 个采点), 岩性为微晶灰岩; 那 益雄组采样 38 块 (5 个采点), 岩性为灰绿色含砾凝灰 岩、紫红色玄武岩. 样品的采集使用 Mode1Do26-T6 便携式钻机取岩芯样品, 配合使用 Mode1OR-2 定向 器和磁罗盘对钻孔岩芯进行定向, 利用 GPS 测定采 样点地理坐标经、纬度值.

\section{2 岩石磁学研究}

为了鉴定标本中的主要磁性矿物, 在每个采点 中选取 1 块代表性样品, 进行了饱和等温剩磁(SIRM) 和三轴等温剩磁的系统热退磁实验 ${ }^{[14]}$. 等温剩磁的 获得采用 2G-660 脉冲磁力仪, 三轴等温剩磁通过对 样品的三个相互正交的 $Z, Y$ 和 $X$ 轴分别施加 2700 , 500 和 $50 \mathrm{mT}$ 的脉冲磁场获得. 等温剩磁的测量采用 JR-5A 旋转磁力仪, 而三轴等温剩磁的系统热退磁采 用 MMTD-48 热退磁炉和 2G-755R 低温超导磁力仪. 所有室内实验工作均在中国科学院地质与地球物理 研究所古地磁学实验室进行 ${ }^{[15]}$.

根据上述岩石磁学实验所揭示出的样品的矫顽 力谱和阻挡温度谱特征, 可将样品的主要磁性矿物 组合分为以下几种类型(图 2): (1) 以磁铁矿为主, 赤 铁矿很少或几乎不存在. 这种类型样品的饱和等温 剩磁曲线在较低的磁化场阶段(约小于 $200 \mathrm{mT}$ )迅速 达到准饱和. 三轴等温剩磁的热退磁曲线显示, 样品 中软磁成分和中间磁成分占主导且具有约 $580^{\circ} \mathrm{C}$ 左右 的阻挡温度. 综合以上特征判断, 这些样品中主要载 磁矿物为低矫顽力的磁铁矿. 此类样品主要是那益 雄组的灰绿色凝灰岩(图 2(a)), 诺日巴嘎日堡组的部 分泥质粉砂岩(图 2(b)). (2) 赤铁矿和磁铁矿共存. 此 类样品的饱和等温剩磁曲线在较低的磁化场(通常小 于 $200 \mathrm{mT}$ )下有一迅速达到饱和的趋势, 之后随着外 加磁场的增强缓慢增加, 至 $2.7 \mathrm{~T}$ 时基本达到饱和. 三轴等温剩磁的热退磁曲线显示, 软磁成分和中间 磁成分在 $580^{\circ} \mathrm{C}$ 左右解阻, 硬磁成分和部分中间磁成 分表现出 $670^{\circ} \mathrm{C}$ 左右解阻温度特征. 以上特征表明, 这类样品具有磁铁矿和赤铁矿共存的特征. 此类型 样品为九十道班组的微晶灰岩(图 2(c), (d)), 扎日根 组灰岩(图 2(e)), 那益雄组安山岩(图 2(f)), 以及诺日 巴嘎日堡组的泥岩(图 2(g)). (3) 少部分样品表现出 赤铁矿为主的特征. 部分诺日巴嘎日堡组的粉砂岩 样品(图 2(h)), 饱和等温剩磁曲线随外加磁场增强, 至 $2.7 \mathrm{~T}$ 仍未达到饱和的趋势. 三轴等温剩磁的热退 磁曲线显示，软磁成分分量很低，中间磁成分和硬磁 成分占主导地位, 两者具有约 $670^{\circ} \mathrm{C}$ 左右的阻挡温度, 表现出赤铁矿为主的特征. 此外, 九十道班组灰岩样 品和诺日巴嘎日保组的粉砂岩样品(图 2(d), (k)), 中 间和硬磁成分在 $80^{\circ} \mathrm{C}$ 的显著衰减还指示了部分针铁 


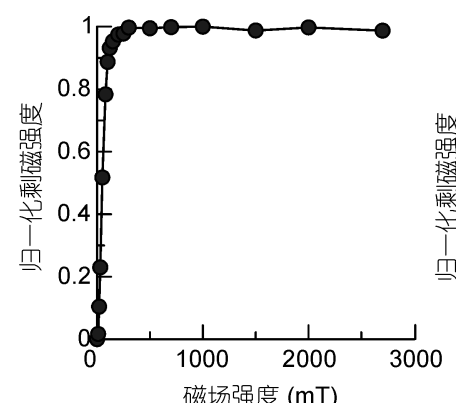

(a) Pn1206

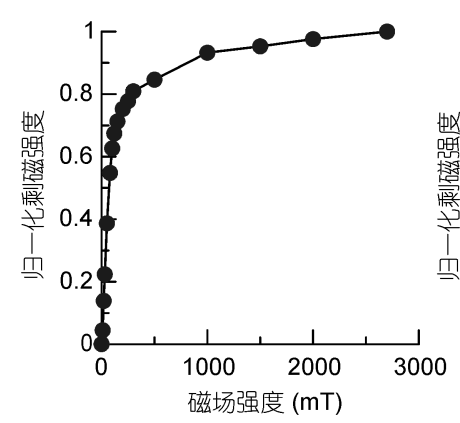

(c) Pj0104

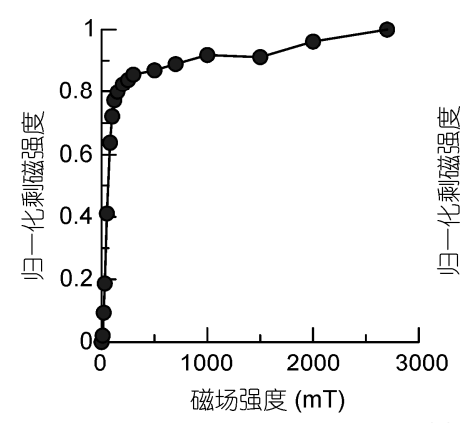

(e) $\mathrm{C} 0311$

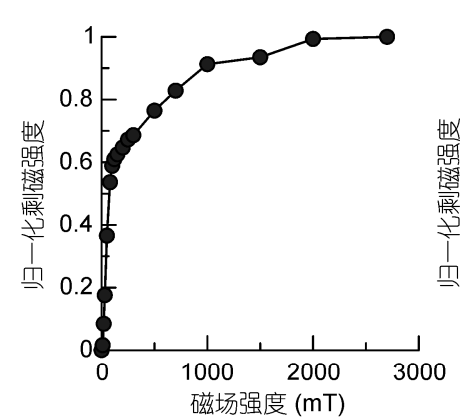

(g) Pnr0201
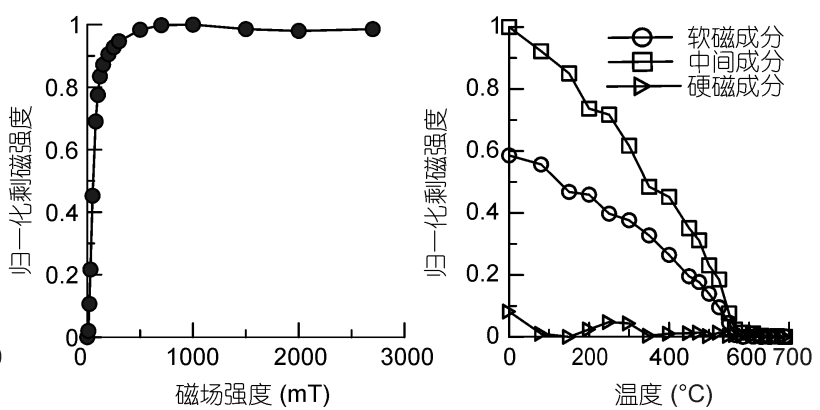

(b) Pnr1102
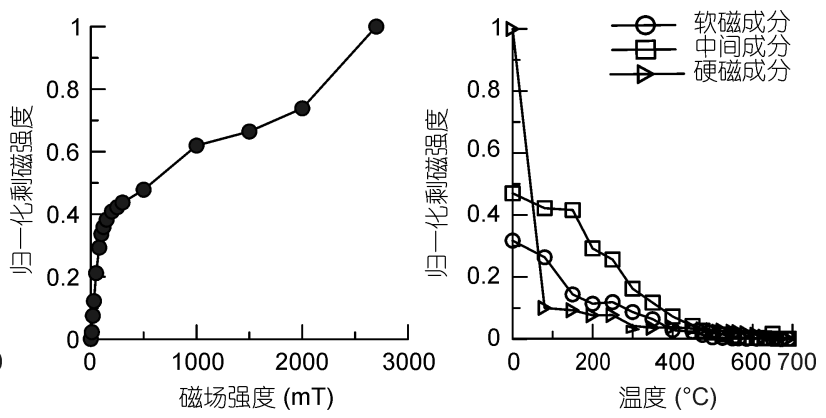

(d) Pj0404
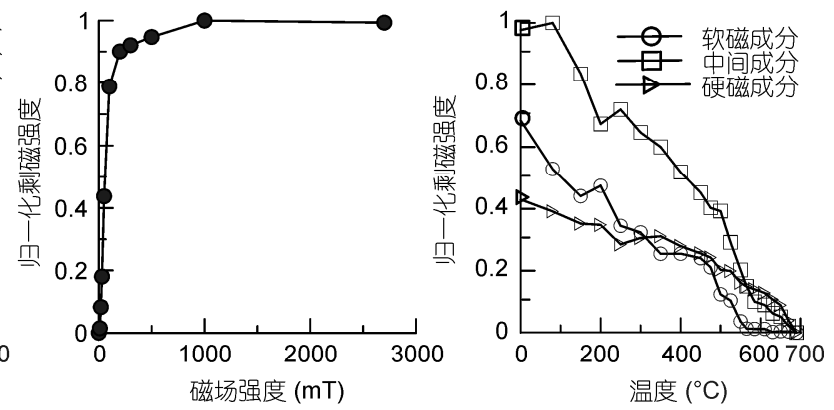

(f) Pn1505
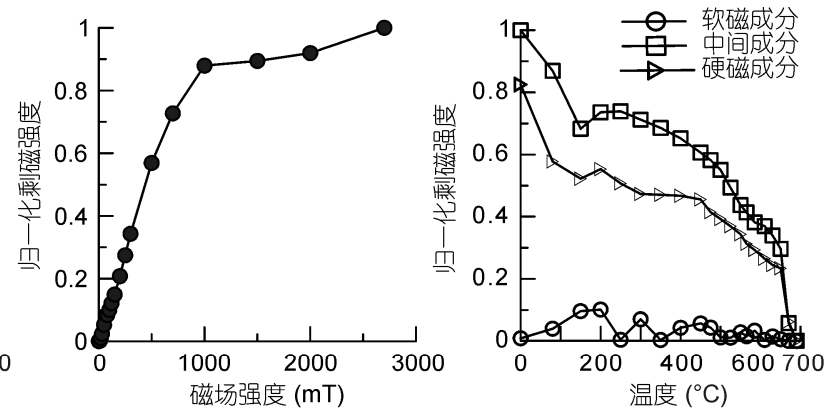

(h) Pnr2321

图 2 代表性样品等温剩磁获得曲线((a), (c), (e), (g))及三轴等温剩磁热退磁曲线((b), (d), (f), (h))

软磁成分 $(<0.04 \mathrm{~T})$; 中间磁成分 $(0.04 \sim 0.4 \mathrm{~T})$; 硬磁成分 $(0.4 \sim 2.7 \mathrm{~T})$

矿的存在.

综上所述, 扎日根组和九十道班组灰岩样品, 以 及那益雄组安山岩样品中赤铁矿和磁铁矿共存; 那
益雄组凝灰岩样品主要载磁矿物为磁铁矿; 诺日巴 嘎日堡组的碎屑岩样品中载磁矿物最为复杂, 为磁 铁矿、赤铁矿、或赤铁矿和磁铁矿共存. 


\section{3 古地磁结果分析}

根据岩石磁学结果, 选择逐步热退磁或交变退 磁, 或者最高温度小于 $300^{\circ} \mathrm{C}$ 的逐步热退磁和交变退 磁的复合退磁方法对全部样品进行了系统磁清洗, 以获得稳定的特征剩磁分量 $(\mathrm{ChRM})$. 系统热退磁使 用 MMTD-48 热退磁炉, 热退磁的温度间隔在低温阶 段选择 $50 \sim 100^{\circ} \mathrm{C}$, 高温阶段为 $10 \sim 25^{\circ} \mathrm{C}$; 交变退磁采 用 $2 \mathrm{G} 600$ 交变退磁仪, 退磁间隔为 5 10 mT. 剩磁测 量在 $2 \mathrm{G}-755 \mathrm{R}$ 低温超导磁力仪上完成. 样品的退磁 和测量均在中心小于 $300 \mathrm{nT}$ 的磁屏蔽空间中进行. 退磁结果投影到正交矢量图 ${ }^{[16]}$ 及赤平投影图, 剩磁 组分的分离主要采用 Kirschvink 主向量分析法 ${ }^{[17]}$, 部
分样品使用重磁化大圆弧法 ${ }^{[18]}$; 剩磁方向的统计平 均采用球面单位矢量的 Fisher 统计平均 ${ }^{[19]}$ 或单位矢 量和重磁化大圆弧的混合平均 ${ }^{[20]}$.

\section{1 晚石炭世扎日根组}

扎日根组灰岩样品的退磁曲线具有典型的双分 量特征. 低温分量通常在 $300^{\circ} \mathrm{C}$ (或 $25 \mathrm{mT}$ ) 以前被清 除, 特征剩磁分量通常出现在 $400 \sim 585^{\circ} \mathrm{C}$ 之间(图 3(a) (c)), 或 30 89 mT 的高场阶段(图 3(d), (e)), 个 别样品直到 $670^{\circ} \mathrm{C}$ 左(右解阻(图 3(f)). 低温分量平均 方向在地层校正前为: $D_{\mathrm{g}}=164.1^{\circ}, I_{\mathrm{g}}=-10.2^{\circ}, k=7.2$, $\alpha_{95}=12.4^{\circ}$. 在总计 33 块样品的系统退磁中, 26 块样 品分离出稳定的特征剩磁分量包括 3 条重磁化弧),

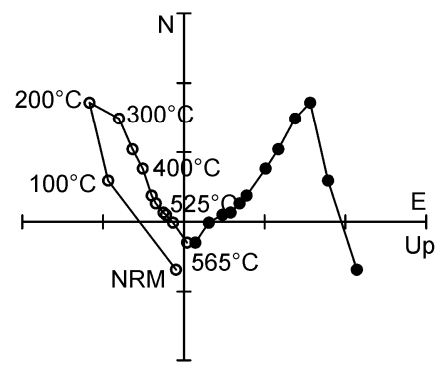

(a) C0101刻度: $2 \mathrm{~mA} / \mathrm{m}$

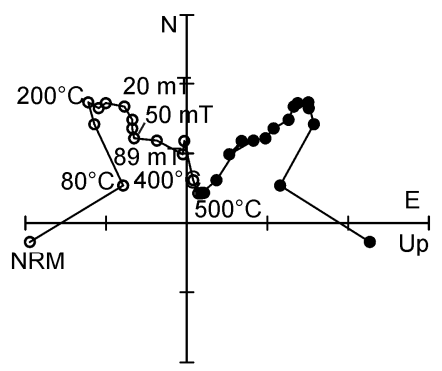

(d) C0301刻度: $1 \mathrm{~mA} / \mathrm{m}$

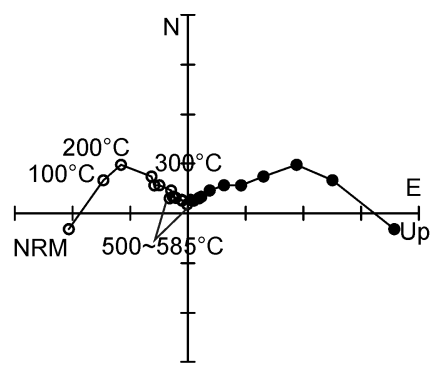

(b) C0201刻度: $0.2 \mathrm{~mA} / \mathrm{m}$

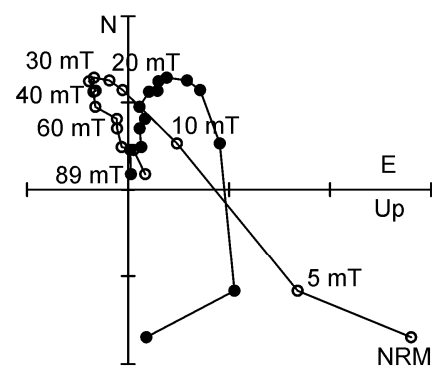

(e) C0401刻度: $0.05 \mathrm{~mA} / \mathrm{m}$

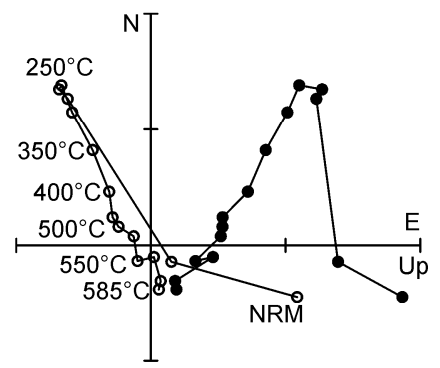

(c) C0105刻度: $2 \mathrm{~mA} / \mathrm{m}$

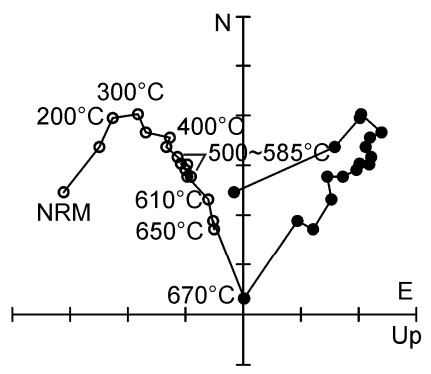

(f) $\mathrm{C} 0305$ 刻度: $1 \mathrm{~mA} / \mathrm{m}$

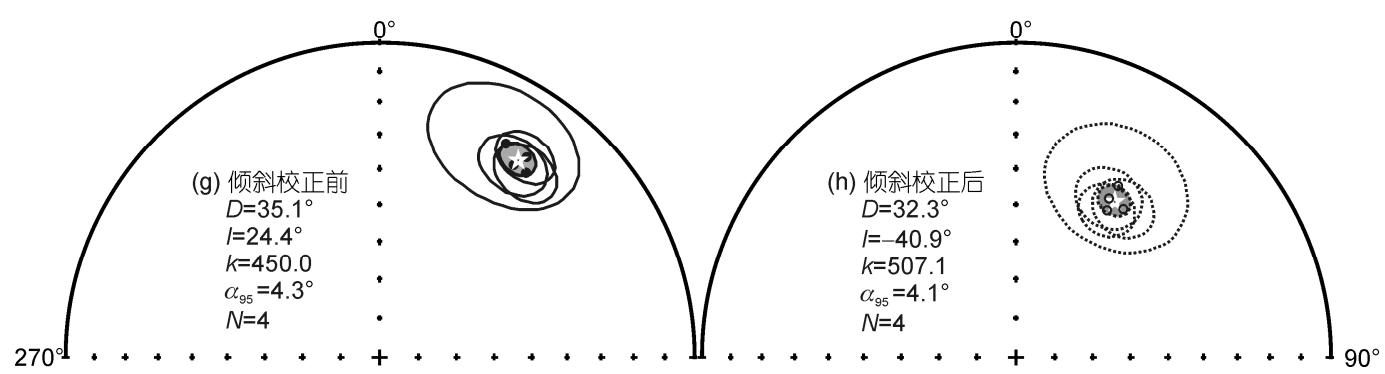

图 3 扎日根组代表样品倾斜校正前的系统退磁矢量 $\mathbf{Z}$ 氏图((a) (f)) 及高温特征分量采点平均方向的 等面积赤平投影图 $((\mathbf{g}),(\mathbf{h}))$

$\mathrm{Z}$ 氏图中的实心圆和空心圆分别代表剩磁方向在水平面和铅垂面上的投影; 赤平投影图中的实心圆和空心圆分别代表负倾角和正倾角, 五角星指示采点平均方向 
所有样品的特征剩磁分量均表现为指向北的负倾角 (正极性). 经 Fisher 统计平均后, 特征剩磁分量的平 均方向在地层校正前后分别为: $D_{\mathrm{g}}=35.1^{\circ}, I_{\mathrm{g}}=24.4^{\circ}$, $k=450.0, \quad \alpha_{95}=4.3^{\circ}$ 和 $D_{\mathrm{s}}=32.3^{\circ}, I_{\mathrm{s}}=-40.9^{\circ}, k=507.1$, $\alpha_{95}=4.1^{\circ}$ (图 3(g), (h)). 由于采样剖面为单斜层, 无法 进行常规的褶皱检验, 但无论是在采点水平上还是 在样品水平上, 经地层产状校正后, 特征剩磁分量的 集中程度均有一定程度提高. 该组分层面坐标下的 平均方向对应的极位置为: $\left(23.7^{\circ} \mathrm{N}, 237.5^{\circ} \mathrm{E}\right)$, $\mathrm{d} p / \mathrm{d} m=9 / 5.4$.

\section{2 中二叠世诺日巴尔日堡组}

诺日巴尔日堡组泥岩、泥质粉砂岩和粉砂岩的退 磁曲线较为复杂, $300^{\circ} \mathrm{C}$ (或 $25 \mathrm{mT}$ )之前可以消除低温 粘滞剩磁. 多数样品在 $350 \sim 525^{\circ} \mathrm{C}$ (或 $30 \sim 70 \mathrm{mT}$ )之间 可以获得一个稳定的剩磁分量 (图 4(a), (b)), 部分采 点样品在 500 640 ${ }^{\circ} \mathrm{C}$ 之间可以获得此分量(图 4(c)). 除 3 个粉砂岩采点或未能分离出有统计意义的特征 剩磁分量, 共有 7 个采点获得有效特征剩磁分量, 经 Fisher 统计平均后, 7 个采点特征剩磁分量的平均方 向在产状校正前后分别为: $D_{\mathrm{g}}=39.6^{\circ}, I_{\mathrm{g}}=44.9^{\circ}, k=75.1$, $\alpha_{95}=7^{\circ}$ 和 $D_{\mathrm{s}}=69.9^{\circ}, I_{\mathrm{s}}=43.5^{\circ}, k=26, \alpha_{95}=12.1^{\circ}$ (图 4(d), (e)). 该组分具有显著的负的褶皱检验结果 $\left(k_{\mathrm{g}} / k_{\mathrm{s}}=\right.$
$75.1 / 26)$, 逐步校正分析 ${ }^{[21]}$ 表明其最大集中程度出现

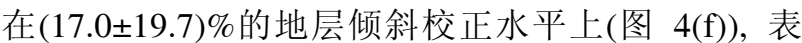
明其应该为褶皱后获得的重磁化组分. 诺日巴尔日 堡组碎屑岩很可能未能保留岩石形成时期的原生剩 磁分量.

\section{3 中二叠世九十道班组}

九十道班组灰岩样品的天然剩余磁化强度 $(\mathrm{NRM})$ 较弱, 其平均值为 $1.23 \times 10^{-3} \mathrm{~A} / \mathrm{m}$ (49 块). 热退 磁至 $500^{\circ} \mathrm{C}$ 左右, 剩磁强度通常降到 $1 \times 10^{-5}$ 以下，难 以继续进行退磁(图 5(f)). 而采用系统交变退磁方法 显示，样品具有典型的双分量特征，低温分量在 20 $\mathrm{mT}$ 以下被清洗, 特征剩磁分量通常出现在 25 89 mT 的高场区(图 5(a) (e)). 共有 5 个采点 42 块样品被分 离出稳定的特征剩磁分量, 其平均方向在产状校正 前后分别为: $D_{\mathrm{g}}=336.7^{\circ}, I_{\mathrm{g}}=62.6^{\circ}, k=21.5, \alpha_{95}=16.9^{\circ}$ 和 $D_{\mathrm{s}}=258^{\circ}, I_{\mathrm{s}}=34.4^{\circ}, k=21.7, \alpha_{95}=16.8^{\circ}$ (图 5(g), (h)). 该 组分层面坐标下的平均方向对应的极位置为: $\left(-1^{\circ} \mathrm{N}\right.$, $\left.204.1^{\circ} \mathrm{E}\right), \mathrm{d} p / \mathrm{d} m=19.3 / 11$.

\section{4 晚二叠世那益雄组}

那益雄组灰绿色含砾凝灰岩、紫红色玄武岩样品 的退磁曲线具有以下几类特征: (1) 大部分样品具有

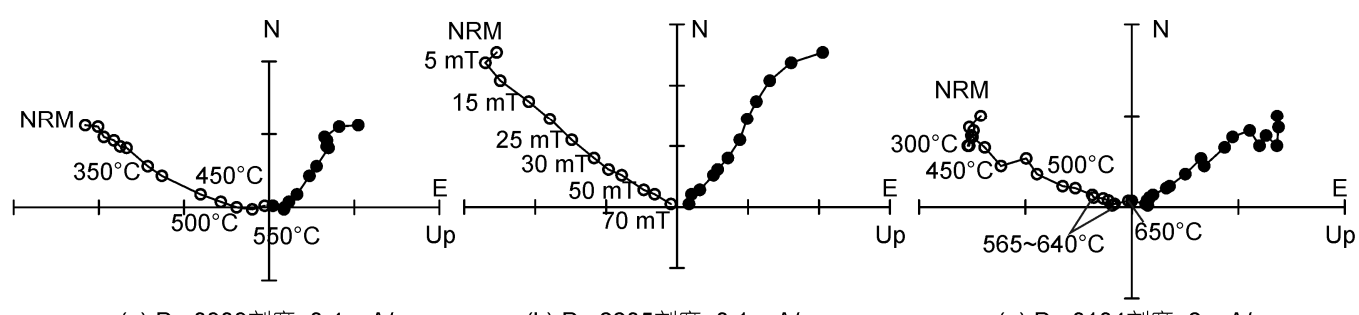

(a) Pnr0303刻度: $0.4 \mathrm{~mA} / \mathrm{m}$

(b) Pnr2205刻度: $0.1 \mathrm{~mA} / \mathrm{m}$

(c) Pnr0104刻度: $2 \mathrm{~mA} / \mathrm{m}$
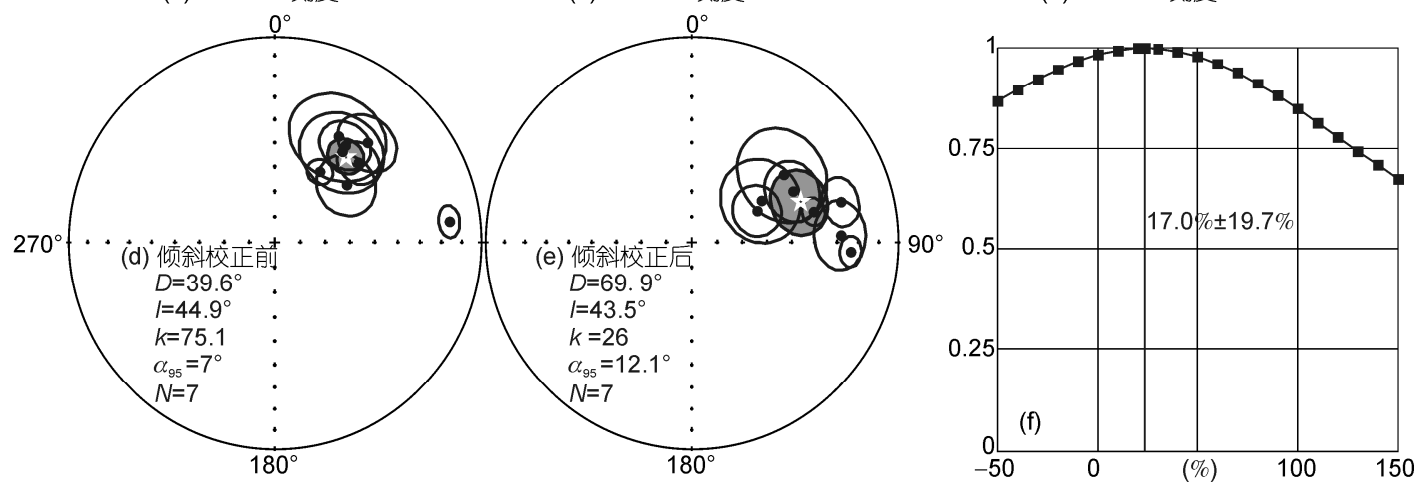

图 4 诺日巴尔日保组代表样品倾斜校正前的系统退磁矢量 $\mathbf{Z}$ 氏图((a) (c)), 高温特征分量采点平均方向的等面积赤平投影 图((d) (e))及其同褶皱检验示意图(f)

$\mathrm{Z}$ 氏图中的实心圆和空心圆分别代表剩磁方向在水平面和铅垂面上的投影. 赤平投影图中的实心圆和空心圆分别代表负倾角和正倾角, 五角星指示采点平均方向 


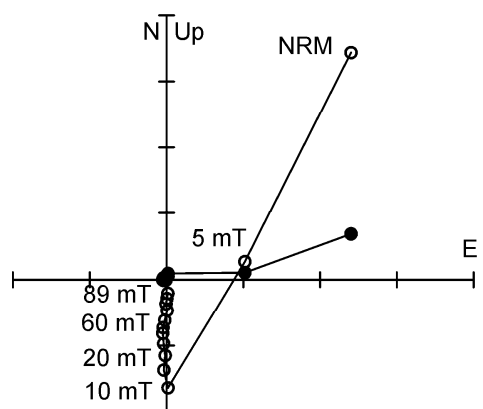

(a) Pj0104刻度: $0.1 \mathrm{~mA} / \mathrm{m}$

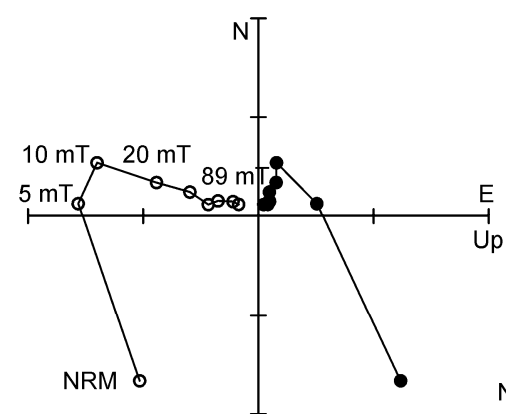

(b) Pj0204刻度: $0.1 \mathrm{~mA} / \mathrm{m}$

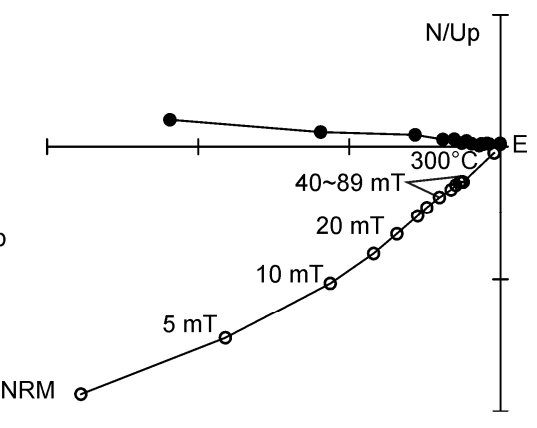

(c) Pj0306刻度: $0.2 \mathrm{~mA} / \mathrm{m}$
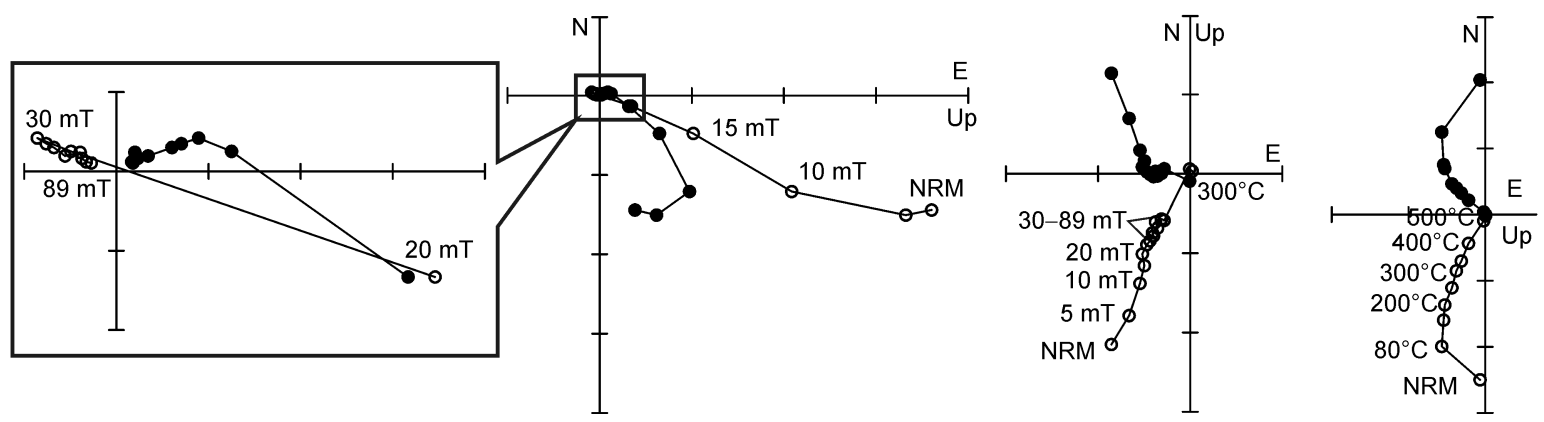

(d) Pj0404刻度: $0.4 \mathrm{~mA} / \mathrm{m}$

$\begin{array}{lll}\text { (e) Pj0505刻度: } 0.2 \mathrm{~mA} / \mathrm{m} & \text { (f) Pj0508刻度: } 0.4 \mathrm{~mA} / \mathrm{m}\end{array}$
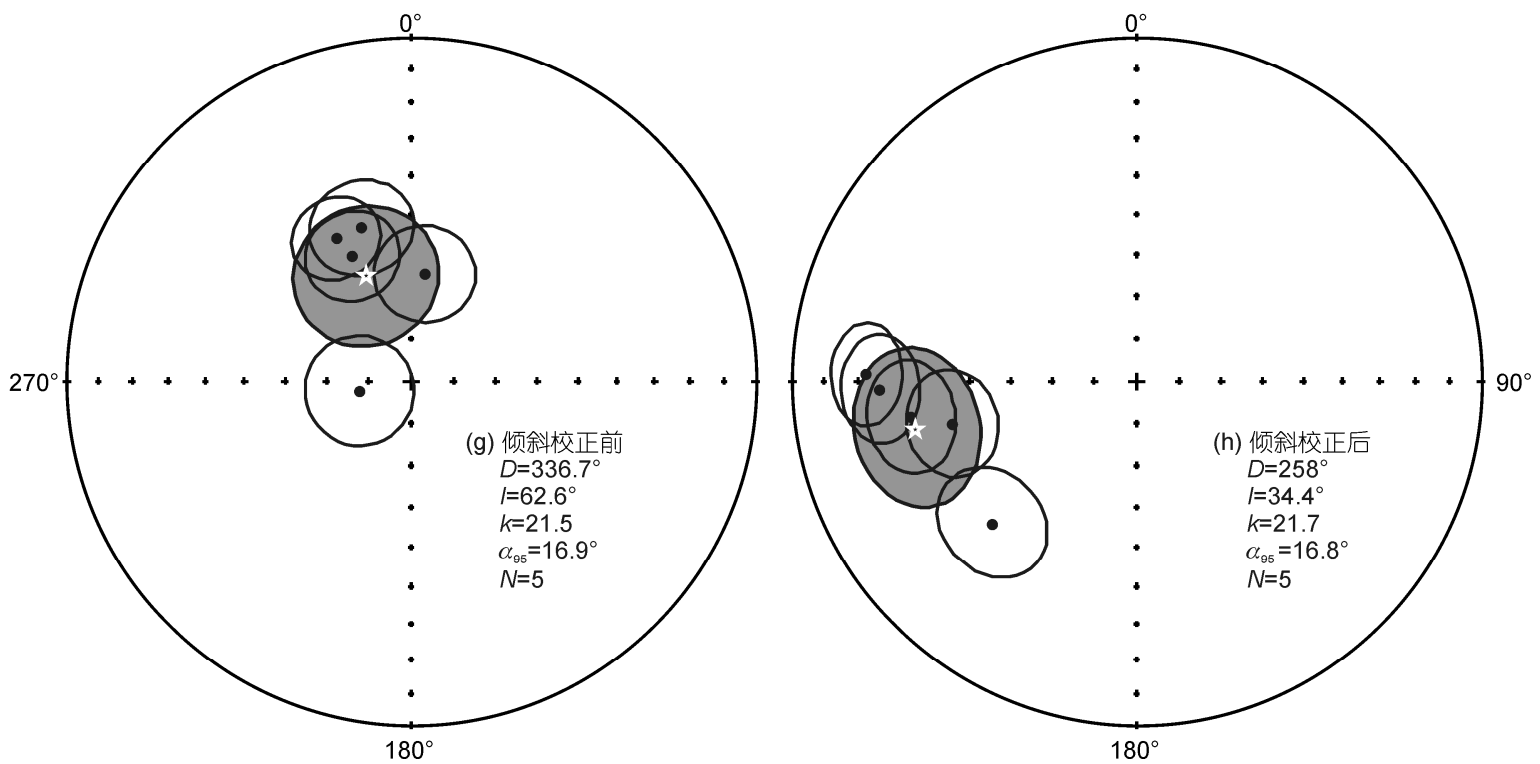

图 5 九十道班组代表样品倾斜校正前的系统退磁矢量 $\mathbf{Z}$ 氏图((a) (f)) 及高温特征分量采点平均方向的 等面积赤平投影图 $((\mathbf{g}),(\mathbf{h}))$

$\mathrm{Z}$ 氏图中的实心圆和空心圆分别代表剩磁方向在水平面和铅垂面上的投影; 赤平投影图中的实心圆和空心圆分别代表负倾角和正倾角, 五角星指示采点平均方向

典型的双分量特征, 在 $500^{\circ} \mathrm{C}$ 以下可以分离出低温分 量, 高温特征剩磁分量通常出现在 $525^{\circ} \mathrm{C}$ 以上, 解阻 于 $670 \sim 690^{\circ} \mathrm{C}$ (图 6(a)，(b))或 $585^{\circ} \mathrm{C}$ (图 6(c)，(d)).(2) 少部分样品显示出单分量的特征, 剩磁强度和方向
在矢量图上表现为一条逼近原点的直线, 直至 $585^{\circ} \mathrm{C}$ 解阻, 其地层坐标系下的矢量方向与双分量样品的 高温特征剩磁分量相近(图 6(e), (f)). (3) 部分凝灰岩 样品难以用主向量分析法 ${ }^{[17]}$ 获取高温特征剩磁分量, 
但其退磁曲线显示出较好的重磁化大圆弧的特征(图 $\quad D_{\mathrm{g}}=357^{\circ}, I_{\mathrm{g}}=35^{\circ}, k=23.8, \alpha_{95}=5.3^{\circ}$, 应该是后期粘滞 $6(\mathrm{~g}),(\mathrm{h}))$, 对这些样品采用重磁化大圆弧法 ${ }^{[18]}$ 进行分 剩磁. 共有 39 块样品分离出稳定的特征剩磁分量, 析. 32 块样品的低温剩磁分量倾斜校正前的平均方向: 其均表现为指向南的正倾角(反极性). 经 Fisher 统

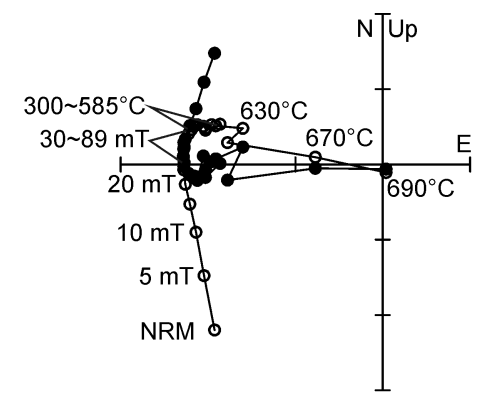

(a) Pn1202刻度: $4 \mathrm{~mA} / \mathrm{m}$

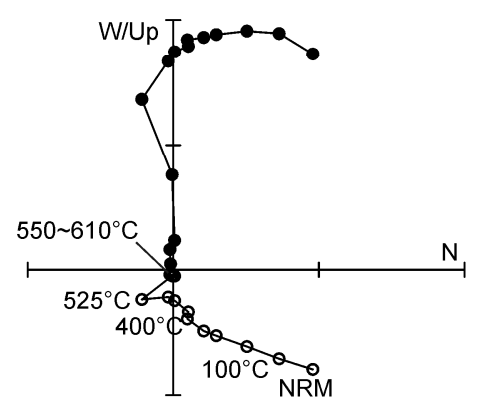

(d) Pn1504刻度: 40 mA/m

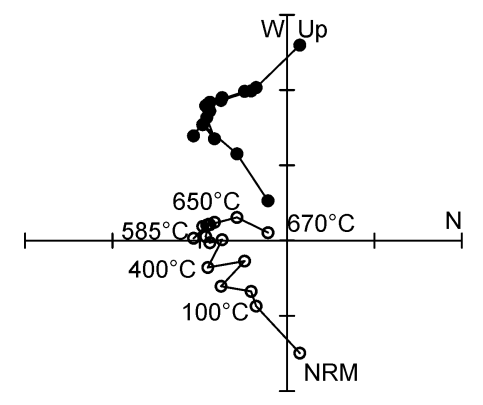

(b) Pn1203刻度: $5 \mathrm{~mA} / \mathrm{m}$

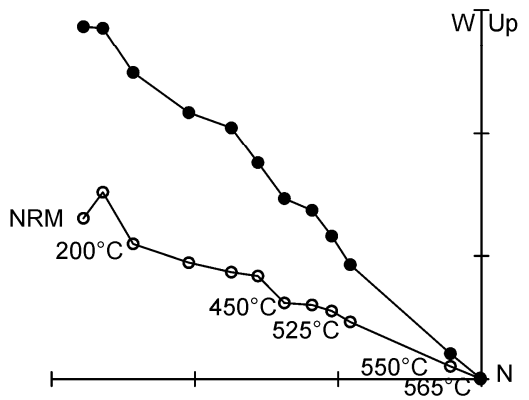

(e) Pn1406刻度: 40 mA/m

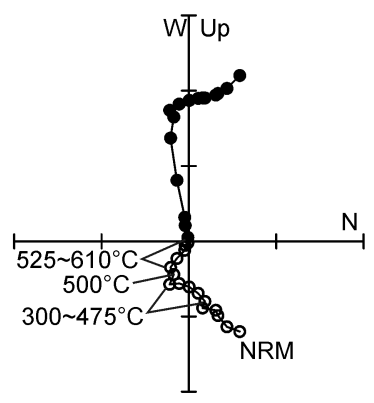

(c) Pn1502刻度: $40 \mathrm{~mA} / \mathrm{m}$

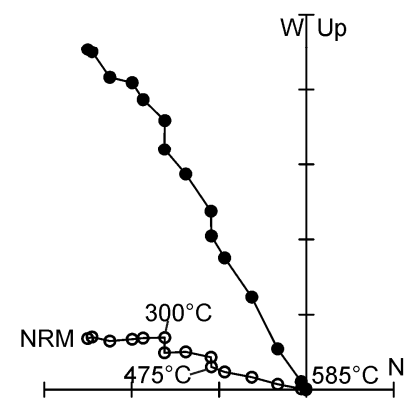

(f) Pn1407刻度: $40 \mathrm{~mA} / \mathrm{m}$

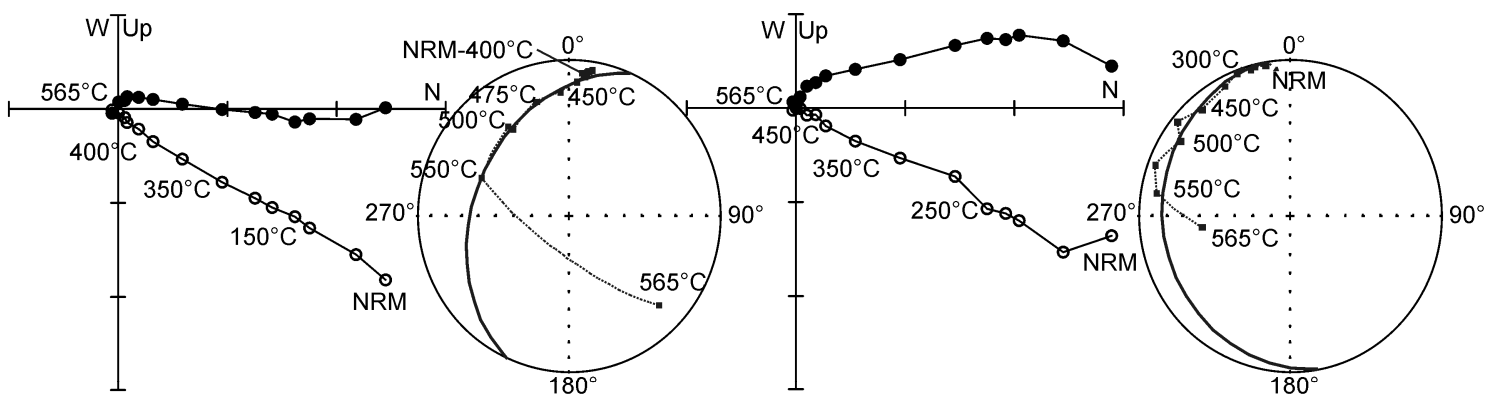

(g) Pn1104刻度: 4 mA/m

(h) Pn1305刻度: $4 \mathrm{~mA} / \mathrm{m}$

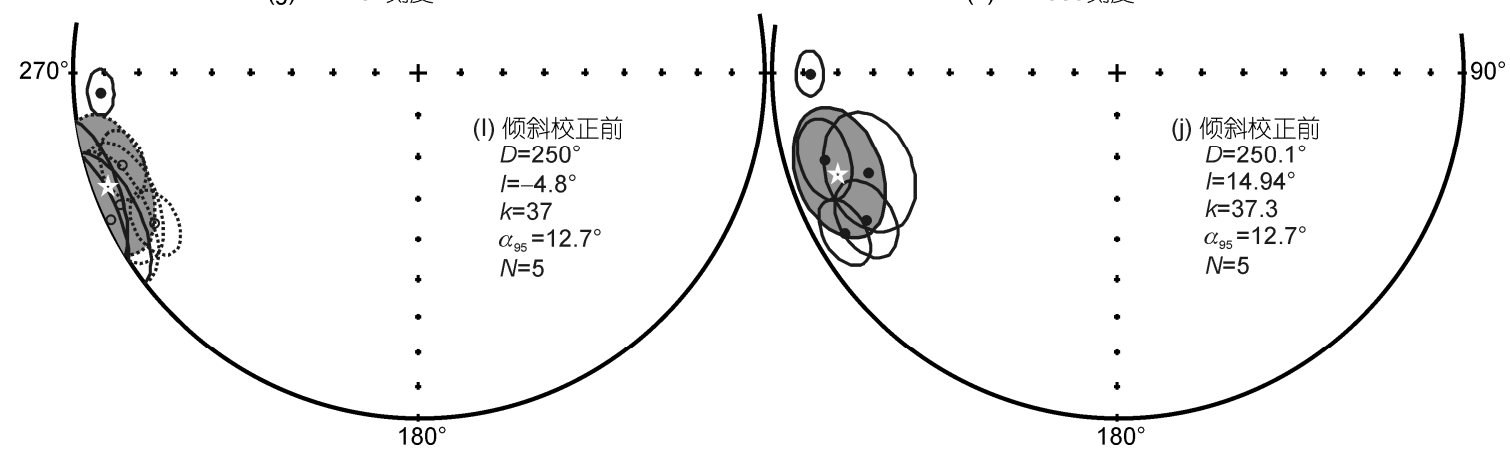

图 6 那益雄组代表样品倾斜校正前的系统退磁矢量 $\mathbf{Z}$ 氏图((a) (f)), 部分样品地层坐标系下退磁矢量的赤平投影图((g),(h)) 及高温特征分量采点平均方向的等面积赤平投影图((i), (j))

$\mathrm{Z}$ 氏图中的实心圆和空心圆分别代表剩磁方向在水平面和铅垂面上的投影; 赤平投影图中的实心圆和空心圆分别代表负倾角和正倾角, 五 角星指示采点平均方向 
计平均后,特征剩磁分量的平均方向在产状校正前后 分别为: $D_{\mathrm{g}}=250^{\circ}, I_{\mathrm{g}}=-4.8^{\circ}, k=37, \alpha_{95}=12.7^{\circ}$ 和 $D_{\mathrm{s}}=250.1^{\circ}, I_{\mathrm{s}}=14.9^{\circ}, k=37.3, \alpha_{95}=12.7^{\circ}$ (图 6(i), (j)). 该 组分层面坐标下的平均方向对应的极位置为: $\left(11.8^{\circ} \mathrm{N}, 198.2^{\circ} \mathrm{E}\right), \mathrm{d} p / \mathrm{d} m=12.2 / 6.2$.

\section{4 数据可靠性论证}

藏东地区晚石炭-晚二叠世样品的古地磁学研究 表明, 晚石炭世扎日根组的 4 个灰岩采点的特征剩磁 分量均为正极性, 由于采样剖面为单斜层, 无法进行 标准的褶皱检验 ${ }^{[2223]}$, 但无论是在采点水平上还是 在样品水平上, 经地层产状校正后, 特征剩磁分量的 分布相对集中, 精度参数 $k$ 值增大. 中二叠世九十道 班组灰岩和晚二叠世那益雄组凝灰岩、玄武岩的特征 剩磁分量均为负极性, 与 Kiaman 负极性段 $(\mathrm{KRS})^{[24]}$ 相吻合. 由于采样区中、晚二叠世九十道班组和那益 雄组分别位于周琼玛鲁复式背斜的两翼(图 1, 表 1), 采样剖面均为单斜层, 单独无法进行常规的褶皱检 验. 研究区中、上二叠统之间为平行不整合接触, 在 构造形态和变形样式上存在一致性, 可作为同一构 造层进行区域性褶皱检验. 将九十道班组和那益雄 组两组的特征剩磁分量放在一起统计时则可发现, 其平均方向在产状校正前后分别为: $D_{\mathrm{g}}=266.8^{\circ}$, $I_{\mathrm{g}}=26.2^{\circ}, k=2.8, \alpha_{95}=31.7^{\circ}$ 和 $D_{\mathrm{s}}=253.5^{\circ}, I_{\mathrm{s}}=22.5^{\circ}, k=23.2$, $\alpha_{95}=9.2^{\circ}$, 通过了标准的褶皱检验 (图 7, 表 1$)^{[22,23]}$. 区域上二叠统乌丽群与上三叠统结扎群之间缺失中 下三叠统沉积, 并且表现为角度不整合接触关系 ${ }^{[2] 11)}$, 代表了印支运动在该区的存在, 故区域性褶皱变形
最早发生在早中三叠世. 因此, 中上二叠统岩石能够 保存 Kiaman 负极性的磁化信息以及特征剩磁分量正 的褶皱检验结果表明, 其完全可能为岩石形成时期 获得的原生剩磁. 而晚石炭世扎日根组的剩磁方向 为单一正极性, 倾角为负值, 与 Kiaman 反极性期之 前的正极性特征相吻合，其对应的极位置显著区别 于㒸北地块晚古生代以后的任一极位置, 此磁化分 量也应该为岩石形成时期的原生剩磁信息.

\section{5 古地磁数据指示的大地构造意义}

㒸北与昌都地块之间为北澜沧江带, 由于藏东 地区经历了长期复杂的构造演化过程和大规模的走 滑, 严重地改造了原有地质面貌, 对研究北澜沧江洋 的构造演化, 以及冈瓦纳大陆北界等带来了极大的 困难. 王根厚等 ${ }^{[9]}$ 认为在早、中二叠世澜沧江带转换 为冈瓦纳北界, 㒸北和昌都分别为古特提斯多岛洋 的中间岛块, 晚二叠世澜沧江洋脊带俯冲-消减-软碰 撞. 李才等 ${ }^{[10]}$ 提出北澜沧江带是藏东地区连接滇西 澜沧江缝合带与龙木错-双湖缝合带的纽带, 有可能 是藏东地区冈瓦纳板块与扬子板块界线; 本文的研 究结果可为这些问题的解决提供证据.

我们曾在芫北保护站-热觉茶卡一带获得晚石炭早三叠世古地磁数据, 该结果通过了褶䏢检验、倒转 检验、岩脉检验等野外地质检验，代表了芫北地块相 应时代的原生剩磁信息 ${ }^{[8]}$. 对比藏东(昌都)和羌北地 块的古地磁结果(表 2, 图 8): (1) 如果选择本文获得 的古地磁极作为参考极, 以㒸北采样点 $\left(33.7^{\circ} \mathrm{N}\right.$, $86.7^{\circ} \mathrm{E}$ ) 作为参考点, 计算该参考点相应时代的期望
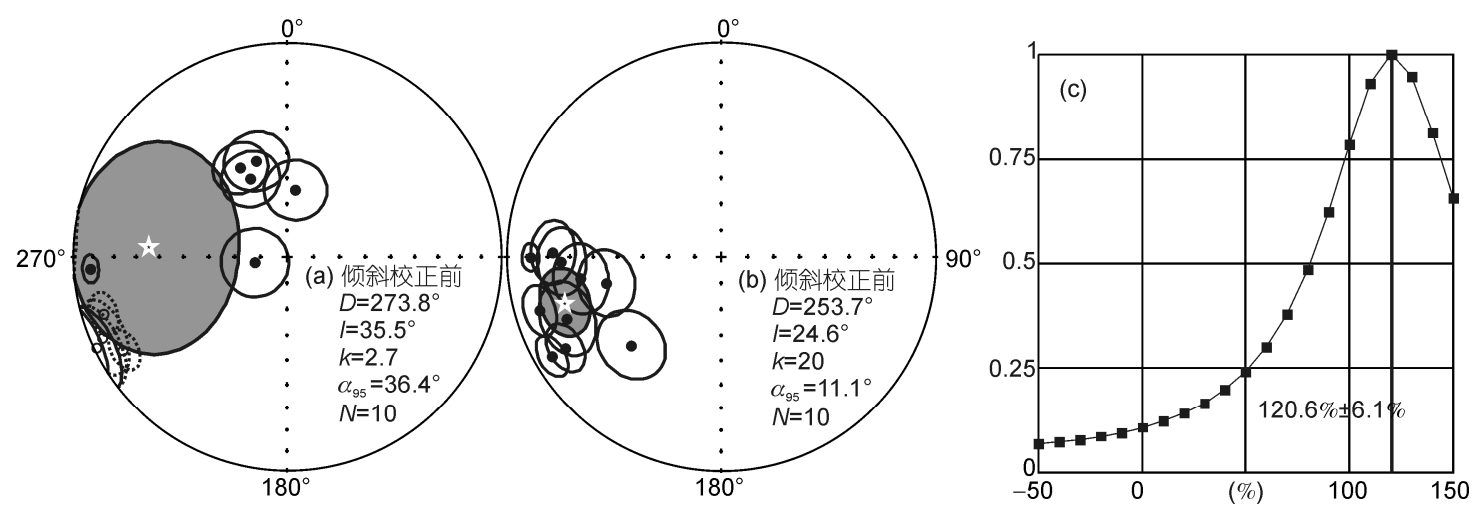

图 7 藏东中晚二叠世高温特征剩磁分量褔皱检验示意图

实心圆和空心圆分别代表负倾角和正倾角，五角星指示采点平均方向 
表 1 藏东地区晚石炭-晚二叠世样品的特征剩磁分量 ${ }^{a)}$

\begin{tabular}{|c|c|c|c|c|c|c|c|c|c|c|c|}
\hline \multirow{2}{*}{ 采点 } & \multicolumn{2}{|c|}{ 采样位置 } & \multirow{2}{*}{ 岩性 } & \multirow{2}{*}{$\begin{array}{c}\text { 倾向/ } \\
\text { 倾角 }\left({ }^{\circ}\right)\end{array}$} & \multirow{2}{*}{$n / N$} & \multirow{2}{*}{$D_{\mathrm{g}}$} & \multirow{2}{*}{$I_{\mathrm{g}}$} & \multirow{2}{*}{$D_{\mathrm{s}}$} & \multirow{2}{*}{$I_{\mathrm{s}}$} & \multirow{2}{*}{$k$} & \multirow{2}{*}{$\alpha_{95}$} \\
\hline & 东经 $\left({ }^{\circ}\right)$ & 北纬 $\left({ }^{\circ}\right)$ & & & & & & & & & \\
\hline \multicolumn{12}{|c|}{ 晚石炭世扎日根组 } \\
\hline $\mathrm{c} 01$ & 92.36 & 34.07 & 灰岩 & $51 / 69$ & $7 / 7$ & 36.3 & 22.4 & 31.9 & -44.3 & 75.6 & 7 \\
\hline c02 & 92.36 & 34.07 & 灰岩 & $51 / 69$ & $7 / 11$ & 38.5 & 26.2 & 36 & -41.3 & 66.5 & 7.7 \\
\hline $\mathrm{c} 03$ & 92.36 & 34.07 & 灰岩 & $58 / 73$ & $7 / 10$ & 35 & 26.5 & 30.4 & -41.1 & 55.7 & 8.2 \\
\hline c04 & 92.36 & 34.07 & 灰岩 & $29 / 59$ & $5 / 5$ & 30.6 & 22.3 & 30.9 & -36.9 & 21.4 & 17.4 \\
\hline \multicolumn{3}{|c|}{ 采点平均 } & & & $(4 / 4)$ & 35.1 & 24.4 & 32.3 & -40.9 & $450.0 / 507.1$ & $4.3 / 4.1$ \\
\hline \multicolumn{12}{|c|}{ 中二叠世诺日巴嘎日堡组 } \\
\hline Pnr01 & 91.90 & 33.95 & 泥岩 & $129 / 45$ & $5 / 5$ & 51.5 & 53.3 & 87.4 & 28.4 & 43 & 11.8 \\
\hline Pnr02 & 91.90 & 33.95 & 泥岩 & $128 / 42$ & $6 / 8$ & 46.6 & 43.3 & 74.9 & 25.9 & 64.6 & 8.4 \\
\hline Pnr03 & 91.90 & 33.95 & 泥岩 & $121 / 40$ & $8 / 8$ & 32.7 & 56.7 & 76 & 39 & 123.6 & 5 \\
\hline Pnr11 & 91.90 & 33.95 & 泥质粉砂岩 & $165 / 26$ & $7 / 11$ & 43 & 34.3 & 63.3 & 44.3 & 29 & 11.4 \\
\hline Pnr12 & 91.90 & 33.95 & 泥质粉砂岩 & $142 / 25$ & $5 / 5$ & 31 & 39.7 & 53.6 & 44 & 18.7 & 18.1 \\
\hline *Pnr13 & 91.90 & 33.95 & 泥质粉砂岩 & $146 / 9$ & $0 / 7$ & & & & & & \\
\hline *Pnr14 & 91.90 & 33.95 & 泥质粉砂岩 & $131 / 14$ & $6 / 8$ & 56.6 & 19.5 & 60.8 & 15.2 & 4.6 & 35.2 \\
\hline Pnr21 & 91.90 & 33.95 & 粉砂岩 & $174 / 22$ & $9 / 11$ & 36.8 & 44.4 & 59.2 & 57.7 & 11.1 & 16.2 \\
\hline Pnr22 & 91.90 & 33.95 & 粉砂岩 & $181 / 29$ & $10 / 10$ & 36.1 & 41.4 & 64.4 & 61.2 & 25.2 & 9.8 \\
\hline *Pnr23 & 91.90 & 33.95 & 粉砂岩 & $194 / 29$ & $24 / 24$ & 83.3 & 15.7 & 93.5 & 23.7 & 34 & 5.1 \\
\hline \multicolumn{5}{|c|}{ 采点平均 } & $(7 / 10)$ & 39.6 & 44.9 & 69.9 & 43.5 & $75.1 / 26$ & $7 / 12.1$ \\
\hline
\end{tabular}

McElhiny's fold test ${ }^{[23]}: N=7, k_{\mathrm{g}} / k_{\mathrm{s}}=2.89>F(12,12)=2.69$, 在 $95 \%$ 置信水平未通过褶皱检验.

McFadden's fold test ${ }^{[24]}: N=7$, 倾斜校正前 $\xi_{2}=0.637$, 倾斜校正后 $\xi_{2}=5.621,95 \%$ 置信水平下的临界值 $\xi=3.086$, 未通过褶皱检验 中二叠世九十道班组

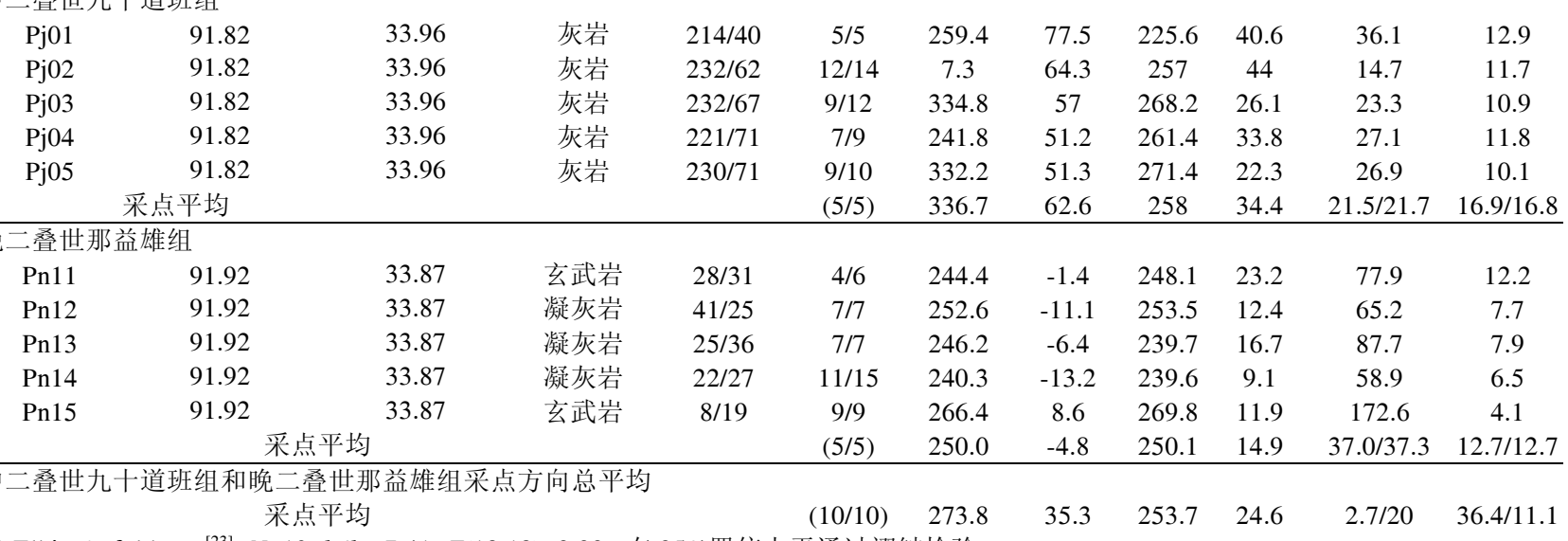

McElhiny's fold test ${ }^{[23]}: N=10, k_{\mathrm{s}} / k_{\mathrm{g}}=7.41>F(18,18)=2.22$, 在 $95 \%$ 置信水平通过褶皱检验

McFadden's fold test ${ }^{[24]}: N=10$, 倾斜校正前 $\xi_{2}=8.804$, 倾斜校正后 $\xi_{2}=2.911,95 \%$ 置信水平下的临界值 $\xi=3.685$, 通过褶皱检验

Watson and Enkin's fold test ${ }^{[21]}$ : 最佳地层校正水平为 $(120.6 \pm 6.1) \%$

a) $N$ 为磁清洗样品数, $n$ 为参与统计样品数; $D_{\mathrm{g}}, I_{\mathrm{g}}\left(D_{\mathrm{s}}, I_{\mathrm{s}}\right)$ 为地理坐标下(地层坐标下)剩磁方向的偏角和倾角; $k, \alpha_{95}$ 为平均方向的 Fisher 统计精度参数和在 $95 \%$ 水平的置信圆锥半顶角; 带“*”采点未参与采点平均

表 2 藏东及㒸北地区晚石炭-早三叠世古地磁数据 ${ }^{\text {a) }}$

\begin{tabular}{|c|c|c|c|c|c|c|c|c|c|c|c|c|c|}
\hline \multicolumn{3}{|c|}{ 采样位置 } & \multirow[b]{2}{*}{ 时代 } & \multicolumn{4}{|c|}{ 地磁极位置 } & \multicolumn{2}{|c|}{ 实测数据 } & \multicolumn{2}{|c|}{ 期望数据 } & \multirow[b]{2}{*}{ 旋转量 $\left({ }^{\circ}\right)$} & \multirow[b]{2}{*}{$\begin{array}{c}\text { 纬向运动量 } \\
\left(^{\circ}\right)\end{array}$} \\
\hline 剖面 & 北纬 $\left({ }^{\circ}\right)$ & 东经 $\left({ }^{\circ}\right)$ & & 北纬 $\left({ }^{\circ}\right)$ & 东经 $\left(^{\circ}\right)$ & $K$ & $\mathrm{~A} 95\left(^{\circ}\right)$ & 偏角 $\left(^{\circ}\right)$ & $\begin{array}{c}\text { 古纬度 } \\
\left.{ }^{\circ}\right)\end{array}$ & 偏角 $\left({ }^{\circ}\right)$ & $\begin{array}{c}\text { 古纬度 } \\
\left({ }^{\circ}\right)\end{array}$ & & \\
\hline \multirow{3}{*}{ 藏东 } & \multirow{3}{*}{34} & \multirow{3}{*}{92} & $\mathrm{P}_{3}$ & 11.9 & 199.7 & 68.6 & 9.3 & 70.1 & -7.6 & & & & \\
\hline & & & $\mathrm{P}_{2}$ & -1 & 204.2 & 28.4 & 14.6 & 78 & -18.9 & & & & \\
\hline & & & $\mathrm{C}_{3}$ & 24.9 & 239.3 & 556 & 3.9 & 32.3 & -23.4 & & & & \\
\hline \multirow{4}{*}{ 㒸北 } & \multirow{4}{*}{33.7} & \multirow{4}{*}{86.7} & $\mathrm{~T}_{1}$ & 16.9 & 202.5 & 33.5 & 6.7 & 61.2 & -10.6 & & & & \\
\hline & & & $\mathrm{P}_{3}$ & 34.4 & 234.1 & 68.6 & 9.3 & 27.5 & -15.4 & 66.9 & -11.8 & $-39.5 \pm 9.9$ & $3.6 \pm 9.1$ \\
\hline & & & $\mathrm{P}_{1-2}$ & 31.7 & 226.8 & 38.4 & 12.5 & 34.3 & -14.5 & 74.8 & -23.2 & $-40.4 \pm 15$ & $-8.7 \pm 13.2$ \\
\hline & & & $\mathrm{C}_{3}$ & 31.8 & 225.7 & 143.1 & 2.9 & 35.1 & -14 & 27.6 & -25.9 & $7.4 \pm 3.9$ & $-11.9 \pm 3.2$ \\
\hline
\end{tabular}

a) 芫北地块古地磁数据引自文献[8]. 旋转量: + / , 逆时针/顺时针; 纬向运动量: + / - 北向漂移/南向漂移 


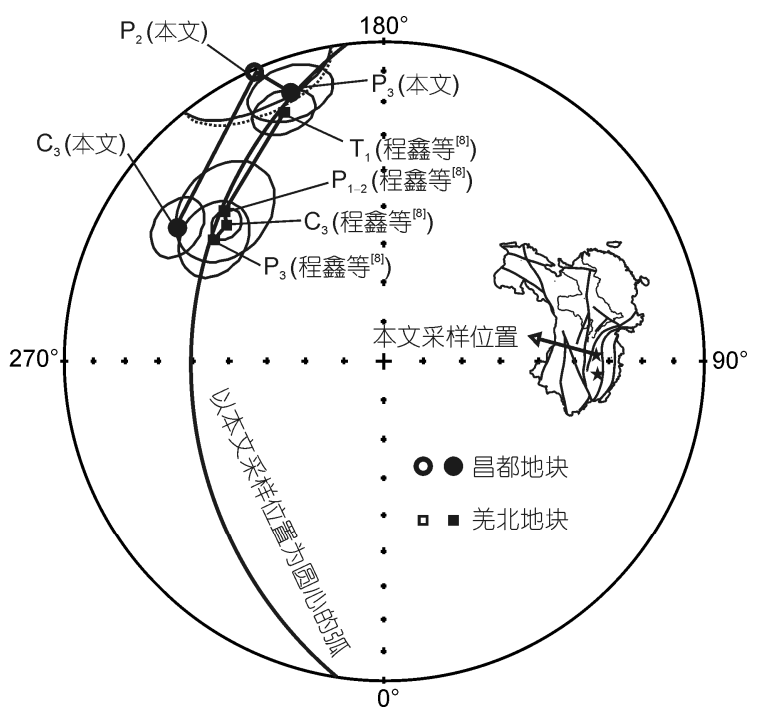

图 8 芫北-昌都地块晚石炭-早三叠世古地磁极位置

古地磁参数, 与其实测数据进行比较不难发现, 晚 石炭世期间两个块体之间可能存在 $11.9^{\circ} \pm 3.2^{\circ}$ 的古 纬度差, 表明㒸北与昌都地块在晚石炭至早中二叠 世可能相互独立，它们之间存在着宽度约 $1300 \mathrm{~km}$
的北澜沧江洋盆, 该洋盆残存的岩石学证据已经被

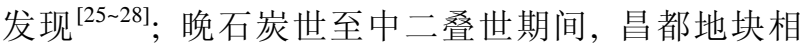
对于羌北地块北移, 并伴随着约 $40^{\circ}$ 的顺时针旋转, 可能预示着两地块之间的北澜沧江洋盆于中二叠世 已经进入俯冲消减和陆-陆碰撞阶段, 造成青藏高原 北部地区普遍存在中晚二叠世的沉积间断 ${ }^{[29]}$; 至中一 晚二叠世, 两地块在纬向上已无显著差异; 晚二叠世 之后姜北地块相对于昌都地块之间的进一步旋转, 完成两地块之间的拼接, 进入陆-陆碰撞阶段。这个 认识得到两地块之间沿澜沧江结合带发育的晚二叠 及早三叠世的碰撞型花岗岩 ${ }^{[30 ~ 32]}$ 的支持. (2) 㒸北昌都地块是属于冈瓦纳大陆最北缘, 还是属于欧亚 大陆最南缘，或者是两大陆之间的独立地体，现在还 不能下定论. 我们的结果可以确定的是，在晚石炭至 早三叠世期间它们主要位于南纬中低纬度地区, 早 三叠世以后, 由于南侧班公湖-怒江洋的开启 ${ }^{[33 \sim 35]}$, 芫北-昌都地块开始了较为快速的北向移动, 拼合至 欧亚大陆南缘，可能在晚三叠世末就完成了这一拼 合过程 ${ }^{[36,37]}$. 与现今位置相比, 㒸北-昌都地块早三 叠世以后北向运动总距离达 $5000 \mathrm{~km}$ 以上.

致谢本研究的实验工作得到中国科学院地质与地球物理研究所黄宝春研究员、秦华峰、蔡书慧、刘成英、乔庆 庆、易治宇等同志的指导和帮助，审稿专家对本文作了认真审阅并提出了许多宝贵意见和修改建议，在此 深表谢意.

\section{参考文献}

1 常承法. 特提斯及青藏碰撞造山带的演化特点. 见: 徐贵忠, 常承法, 主编. 大陆岩石圈构造与资源. 北京: 海洋出版社, 1992. 1-8

2 林金录. 从古地磁看青藏高原地壳增厚机制. 地震地质, 1987, 9: 41-47

3 Chen Y, Wu H N, Courtillot V, et al. Large NS convergence at the northern edge of the Tibetan Plateau? New Early Cretaceous paleomagnetic data from Hexi Corridor, NW China. Earth Planet Sci Lett, 2002, 201: 293-307

4 Otofujia Y, Mu C L, Tanakaa K J. Spatial gap between Lhasa and Qiangtang blocks inferred from Middle Jurassic to Cretaceous paleomagnetic data. Earth Planet Sci Lett, 2007, 262: 581-593

5 李朋武, 高锐, 管烨, 等. 古特提斯洋的闭合时代的古地磁分析：松潘复理石杂岩形成的构造背景. 地球学报, 2009, 30: 39-50

6 孙丽莎, 黄宝春, 陈军山. 青藏高原诸块体的显生宙运动学与特提斯洋的演化. 见: 金翔龙, 秦蕴珊, 朱日祥, 主编. 中国地质地球物理 学研究进展一庆贺刘光鼎院士八十华诞. 北京: 海洋出版社, 2008. 54-65

7 Yi Z Y, Huang B C, Chen J S. Paleomagnetism of early Paleogene marine sediments in southern Tibet, China: Implications to onset of the India-Asia collision and size of Greater India. Earth Planet Sci Lett, 2011, 309: 153-165

8 程金金, 吴汉宁, 计文化, 等. 青藏高原㒸北地块晚古生代古地磁研究的初步结果. 中国科学: 地球科学, 2011, 41: 1100-1108

9 王根厚, 梁定益, 张维杰, 等. 藏东北构造古地理特征及冈瓦纳北界的时空转换. 地质通报, 2007, 26: 921-928

10 李才, 谢尧武, 董永胜, 等. 北澜沧江带的性质是冈瓦纳板块与扬子板块的界线吗? 地质通报, 2009, 28: 1711-1719

11 刘广才. 唐古拉山中段开心岭群乌丽群的时代定义问题. 青海地质, 1993, 2: 1-9

12 潘术娟. 昌都地块西段二叠纪开心岭群沉积特征及其构造意义. 北京: 中国地质大学出版社. 2011

13 牛志军, 徐安武, 王建雄, 等. 青海南部二叠纪罗甸期火山岛沉积相模式及对类动物群分布的制约. 中国科学 $\mathrm{D}$ 辑: 地球科学, 2008, 38: $145-156$. 
14 Lowrie W. Identification of ferromagnetic minerals in a rock coercivity and unblocking temperature properties. Gephys Res Lett, 1990, 17: 159-162

15 朱日祥, 黄宝春, 潘永信, 等. 岩石磁学与古地磁实验室简介. 地球物理学进展, 2003, 18: 177-181

16 Zijderveld J D A. A demagnetization of rocks: Analysis of results. In: Collinson D W, Creer K M, Runcorn S K, eds. Methods on Paleo-magnetic. New York: Elsevier, 1967. 254-286

17 Kirschvink J K. The least-squares line and plane and the analysis of paleomagnetic data. Geophys J R Astron Soc, 1980, 62: 699-718

18 Halls H C. The use of converging remagnetization circles in paleomagnetism. Phys Earth Planet Inter, 1978, 16: 1-11

19 Fisher R A. Dispersion on a sphere. Proc R Soc A-Math Phys Eng Sci, 1953, 217: 295-305

20 McFadden P L, McElhinny M W. The combined analysis of remagnetization circles and direct observations in paleomagnetism. Earth Planet Sci Lett, 1988, 87: 161-172

21 Watson G S, Enkin R J. The fold test in paleomagnetism as a parameter estimation problem. Geophys Res Lett, 1993, 20: 2135-2137

22 McFadden P L. A new fold test foe paleomagnetic studies. Geophys J Inter, 1990, 103: 163-169

23 McElhinny M W. Statistical significance of the fold test in paleomagnetism. Geophys J R Astron Soc, 1964, 8: 338-340

24 Schubert G, Turcotte D L, Olsen P E. Mantle Convection in the Earth and Planets. Cambridge: Cambridge University Press, 2001

25 杨子江, 李咸阳. 藏北若拉冈日结合带中的浅变质地层及其铅石 SHRIMP U-Pb 年龄测定. 地质通报, 2006, 25: 118-123

26 王剑, 汪正江, 陈文西, 等. 藏北北㒸塘盆地那底岗日组时代归属的新证据. 地质通报, 2007, 26: 404-409

27 邓万明. 青藏古特提斯蛇绿岩带与 “冈瓦纳古陆北界”. 见: 张旗, 主编. 蛇绿岩与地球动力学研究. 北京: 地质出版社, 1996. 172-176

28 李才, 谢尧武, 董永胜, 等. 藏东类乌齐一带吉塘岩群时代讨论及初步认识. 地质通报, 2009, 28: 1178-1180

29 陈守建, 李荣社, 计文化, 等. 青藏高原北部地层缺失研究. 地层学杂志, 2006, 30: 231-236

30 杨子江, 李咸阳. 藏北若拉冈日结合带中的浅变质地层及其铅石 SHRIMP U-Pb 年龄测定. 地质通报, 2006, 25: 118-123

31 王保弟, 王立全, 强巴扎西, 等. 早三叠世北澜沧汇结合带碰撞作用: 类乌齐花岗质片麻岩年代学、地球化学及 Hf 同位素证据. 岩 石学报, 2011, 27: 2752-2762

32 陶琰, 毕献武, 李金高, 等. 西藏吉塘花岗岩地球化学特征及成因. 岩石学报, 2011, 27: 2763-2774

33 王忠恒, 王永胜, 谢元和, 等. 西藏班公湖-怒江缝合带中段塔仁本洋岛型型玄武岩的发现及地质意义. 沉积与特提斯地质, 2005, 25: 155-162

34 史仁灯. 班公湖 SSZ 型蛇绿岩年龄对班-怒洋时限的制约. 科学通报, 2007, 52: 223-227

35 李超, 肖传桃, 龚文平, 等. 班公湖怒江缝合带中段构造演化再探讨. 长江大学学报, 2011, 8: 41-43

36 王小峰, Ian Metcalfe, 简平. 金沙江缝合带构造地层划分及时代厘定. 中国科学 D 辑: 地球科学, 1999, 29: 289-297

37 李勇, 王成善, 伊海生. 西藏金沙江缝合带西段晚三叠世碰撞作用与沉积响应. 沉积学报, 2003, 21: 191-197 